Annals of Tropical Research 29[1]:1-13(2007)

(C)LU, Leyte, Philippines

\title{
In vitro culture of rose species (Rosa spp.) via axillary bud growth
}

\author{
Zosimo S. de la Rosa, Jr. and Marilyn M. Belarmino \\ Department of Horticulture, College of Agriculture, \\ Leyte State University, Baybay, Leyte, 6521-A Philippines
}

\begin{abstract}
The utilization of nodal stem cuttings containing dormant axillary buds as explants for plant production of two rose species; Rosa chinensis cv. 'Old Blush' and R. centifolia cv. 'Petite de Hollande' was demonstrated in this study. This propagation technique required the breaking of dormant axillary buds by aseptically culturing them in agarsolidified Woody Plant Medium (WPM) added with 0.5, 1.0, and $2.0 \mathrm{mg} \mathrm{l}^{-1}$ of 6benzylaminopurine (BAP) or, a combination of $2.0 \mathrm{mg} \mathrm{l}^{-1} \mathrm{BAP}$ and $0.01 \mathrm{mg} \mathrm{l}^{-1}$ naphthalene acetic acid (NAA). Production of multiple adventitious shoots from one nodal stem explant was obtained after three months of culture in medium supplemented with 1.0 or $2.0 \mathrm{mg} \mathrm{l}^{-1}$ BAP. Four types of plant morphology; single shoot (type 1), multiple shoots with normal leaves (type 2), cluster of tiny shoots with curly leaves (type 3 ), and single shoot with callus at the base (type 4) were observed from the axillary bud-derived plantlets. The rooting of plantlets was induced in WPM containing 0.25 to $1.0 \mathrm{mg} \mathrm{l}^{-1}$ of indole-butyric acid (IBA) or, $2.0 \mathrm{mg} \mathrm{l}^{-1}$ of indole-3-acetic acid (IAA).
\end{abstract}

Keywords: benzylamino purine, naphthalene acetic acid, nodal stem, woody plant medium

Correspondence: M. M. Belarmino Address: Department of Horticulture, College of Agriculture, Leyte State University, Baybay, Leyte, 6521-A, Philippines.E-mail: lyn3063@yahoo.com.Tel. No. (053) 335-2628; Fax No. (053) 335-2601

DOI: $10.32945 /$ atr2911.2007 
de la Rosa and Belarmino

\section{INTRODUCTION}

Roses (Rosa spp.) represent a major commercial market for cutflowers, potted plants and garden bushes with over $200 \mathrm{M}$ bushes planted worldwide each year (Short and Roberts, 1991 as cited by Marchant et al., 1994). They are also rich sources of raw materials for cosmetic, medicinal and culinary purposes. Roses sold in flower shops and nurseries today are spontaneous or artificially-induced sports (mutations) and hybrids of varied parentage. These do not propagate easily, need sturdy well-rooting rootstock like $R$. multiflora, $R$. canina, and $R$ corymbifera laxa and require intensive cultivation. The old rose cultivars like $R$. chinensis cv. 'Old Blush' and $R$. centifolia cv. 'Petite de Hollande' are gaining back popularity because of their profound hardiness, resistance to pests and diseases and, ease in propagation that make them excellent donors of useful genes.

Plant tissue culture is an alternative to the traditional way of propagating roses thereby eliminating the use of rootstocks (Skirvin et al., 1990), providing an effective worldwide distribution of rose plantlets at a reduced cost and approved by the international phytosanitary board (Schiva, 2001). This technique generates many plants from a selected/new genotype in a relatively short time and less space Reist (1985) as cited by Dubois et al. (1988), in vitro propagated roses sometimes yield more flowers than those propagated by cuttings. They are more compact and branch better when grown ex vitro. For highly heterozygous plants like roses, tissue culture via micropropagation provides stable clones where traditional breeding methods failed.

Reports of direct plant regeneration from axillarybuds have been mainly on rose species such as $R$. hybrida (Miro, 1992; Ara et al., 1997; Kim et al., 2003). Likewise, more hybrid roses were used in studies involving biotechnological approaches compared to old cultivars (Khosh-Khui and Sink, 1982; Hsia and Korban, 1996). Thus, it is important to establish a plant regeneration system in old rose cultivars as requisite for their utilization in varietal improvement and germplasm conservation programs using biotechnological approaches such as genetic transformation and cryopreservation.

This study demonstrated the utilization of axillary buds of nodal stem cuttings to produce plantlets from two rose species, $R$. chinensis cv. 'Old Blush' and $R$. centifolia $\mathrm{cv}$. 'Petite de Hollande'. The medium requirements during initial culture and subsequent plant production and rooting are presented. 
MATERIALS AND METHODS

\section{Care of donor plants}

Mature plants of the two rose species, Rosa chinensis cv. 'Old Blush' and $R$. centifolia cv. 'Petite de Hollande' were used as source of nodal stem cuttings. Routine fertilization using complete fertilizer (16-16-16\% of N, $\mathrm{P}_{2} \mathrm{O}_{5}$, $\mathrm{K}_{2} \mathrm{O}$ ) at 1 tbsp. per two gallons of water and, application of insecticide (Furadan, Bayer Phils. Inc.) at $\sim 10$ granules per plant were done once a month to obtain healthy and vigorous plants. Plants were constantly inspected for bugs and aphids and these were manually removed.

\section{Culture medium and incubation condition}

The basal woody plant medium (WPM) (Lloyd and McCown, 1981 as modified by Flynn et al., 1990) containing myo-inositol (100 $\left.\mathrm{mg} \mathrm{l}^{-1}\right)$, nicotinic acid $\left(0.5 \mathrm{mgl}^{-1}\right)$, pyridoxine. $\mathrm{HCl}\left(0.5 \mathrm{mgl}^{-1}\right)$, thiamine. $\mathrm{HCl}\left(0.7 \mathrm{mgl}^{-1}\right)$, adenine sulphate $\left(0.5 \mathrm{mg} \mathrm{l}^{-1}\right)$, L-leucine $\left(0.4 \mathrm{mgl}^{-1}\right)$, L-arginine $\left(0.4 \mathrm{mg} \mathrm{l}^{-1}\right)$, L-tryptophan $\left(0.2 \mathrm{mg} \mathrm{l}^{-1}\right)$, and glycine $\left(2.0 \mathrm{mg} \mathrm{l}^{-1}\right), 30 \mathrm{~g} \mathrm{l}^{-1}$ refined white table sugar and solidified with $7 \mathrm{~g} \mathrm{l}^{-1}$ agar-agar (Pronadisa ${ }^{\mathrm{TM}}$, Hispanlab, S.A. Madrid) was used in all experiments. The $\mathrm{pH}$ of the medium was adjusted to 5.8 and then, the medium was dispensed at $10 \mathrm{ml}$ in glass vials $(95 \times 28 \mathrm{~mm})$ prior to autoclaving at $1.1 \mathrm{~kg} \mathrm{~cm}^{-2}\left(121^{\circ} \mathrm{C}\right)$ for $20 \mathrm{~min}$. The culture condition was kept under $16 \mathrm{~h}$ photoperiod provided two $40-\mathrm{W}$ cool, white fluorescent tubes (Philips, TL40W/54/RS, Philippines) and $25 \pm 1^{\circ} \mathrm{C}$ unless, otherwise stated.

\section{Experimental design and treatments}

This experiment was laid out in a Completely Randomized Design (CRD). One-way and Univariate analysis of variance were used to analyze the data and Tukey's Honestly Significant Difference test(HSD) was applied to determine significant differences between treatment means.

\section{Preparation of the nodal stem explants}

Three to seven inches of apical stem cuttings containing not more than seven nodes were used as source of axillary buds. The stems were cut into segments containing two to three nodes and then surface sterilized by soaking 
in $70 \%$ ethyl alcohol (ETOH) for 2 min followed by $20 \%$ commercial bleach solution (i.e., Zonrox) for $10 \mathrm{~min}$. Finally, the stems were rinsed three to five times with sterile distilled water. Inside the laminar flow hood, the decontaminated stems were further cut into $\sim 20 \mathrm{~mm}$ single node-stem pieces and inoculated into glass vial $(95 \mathrm{~mm} \times 28 \mathrm{~mm})$ containing $5 \mathrm{ml}$ of culture medium.

\section{Regeneration of plantlets from axillary buds}

The single-node stem segments were inoculated into agar-solidified WPM supplemented with BAP at a range of concentrations $(0.5,1.0$, and $\left.2.0 \mathrm{mg} \mathrm{l}^{-1}\right)$. The medium containing $2.0 \mathrm{mg} \mathrm{l}^{-1} \mathrm{BAP}$ and $0.01 \mathrm{mg} \mathrm{l}^{-1} \mathrm{NAA}$ reportedly effective for axillary bud culture of six hybrid tea cultivars (Kim et al., 2003) was included in the treatments for comparison purposes. The nodal stem cultures were incubated in dark at $25 \pm 1^{\circ} \mathrm{C}$ for 1 to 2 weeks to break the dormancy of axillary buds. Then, these were transferred to culture shelves with reduced light intensity for three weeks immediately followed by full light intensity for one week. The nodal stem cultures were subcultured once at 4 weeks interval to allow emergence of axillary buds. Fully emerged axillary buds were dissected from the nodal stem tissue to allow further growth and proliferation of adventitious shoots. Adventitious shoots bearing at least three to five leaves were individually separated and transferred to fresh culture medium and subcultured once at four weeks interval to allow the proliferation of shoots. The effects of the treatments were evaluated by observing the percentages of nodal stem segments showing tissue necrosis, emerging axillary buds and, shoot growth and development.

\section{In vitro rooting of plantlets and acclimatization}

The axillary bud-derived shoots ( $\sim 10 \mathrm{~mm}$ in length) were transferred to WPM supplemented with combinations of indole-butyric acid(IBA) at 0.25 , 0.5 and $1.0 \mathrm{mg} \mathrm{l}^{-1}$, and indole-3-acetic acid (IAA) at $2.0 \mathrm{mg}^{-1}$ to induce rooting. The medium containing $2.0 \mathrm{mg} \mathrm{l}^{-1} \mathrm{IAA}$ reportedly effective for rooting of shoots from several rose species (Ma et al., 1996) was included in the treatments for comparative purpose. The PGR-free medium served as control. Ten shoots were inoculated per treatment medium and incubated under $16 \mathrm{~h}$ photoperiod at $25 \pm 1^{\circ} \mathrm{C}$. After four weeks, the percentage of shoots producing roots, average length $(\mathrm{mm})$ and number of roots were recorded. The plantlets 
bearing at least three to five leaves and roots were taken out of the culture room and placed at room temperature $\left(28 \pm 2{ }^{\circ} \mathrm{C}\right)$ under $24 \mathrm{~h}$ photoperiod for one to two weeks for acclimatization. Thereafter, the plantlets were removed from the vials, washed of remaining agar and planted in clay pots containing a mixture of sterile vermiculite, compost, and garden soil at 1:1:1 (v/v) or, in Hoagland's nutrient solution (Hoagland and Arnon, 1938) and kept in the acclimatization area for four weeks. A glass cover was provided for each plantlet to simulate the high relative humidity of in vitro condition. After four weeks, the glass covers were removed. The percentage of survival of potted plants was gathered after three months of acclimatization.

\section{RESULTS AND DISCUSSION}

\section{Regeneration of adventitious shoots from axillary buds}

The viable axillary buds of nodal stem segments swelled and protruded while the non-viable buds gradually turned brown and died after two to three weeks of culture in agar-solidified WPM supplemented with BAP or, a combination of BAP and NAA. The viability of axillary buds was affected by the surface sterilization process whereas, the breaking of bud dormancy was influenced by BAP and NAA supplement in the culture medium. Generally, the emergence of axillary buds was observed from the two rose species after three weeks of culture in the BAP and NAA-supplemented medium and after seven weeks in the unsupplemented or control medium. The medium supplemented with $1.0 \mathrm{mg} \mathrm{l}^{-1} \mathrm{BAP}\left(\mathrm{S}_{2}\right)$ induced the highest percentage $(80 \%)$ of emerging buds in R. chinensis cv. 'Old Blush' (Fig. 1). Likewise, the treatment medium $\left(\mathrm{S}_{4}\right)$ containing a combination of higher concentration of BAP $\left(2.0 \mathrm{mg} \mathrm{l}^{-1}\right)$ and lower concentration of NAA $\left(0.01 \mathrm{mg} \mathrm{l}^{-1}\right)$ induced $73.33 \%$ bud emergence in $R$. centifolia $\mathrm{cv}$. 'Petite de Hollande'. On the contrary, the medium lacking plant growth regulators or, control $\left(\mathrm{S}_{0}\right)$ gave low percentage of emerging buds from $R$. chinensis cv. 'Old Blush' $(43.33 \%)$ and

R. centifolia cv. 'Petite de Hollande,' (40.00\%) (Fig. 1). The importance of BAP in breaking the dormancy of buds of rosaceous plants like chestnut, apple, and cherry has been mentioned by Vieitez and Vieitez (1980). BAP has also been found effective for axillary bud growth of tea plants (Nakamura, 1991); R. hybrida L. cv. 'Forever Yours'(Wilkowske, 1981) and cv. 'Peace' 


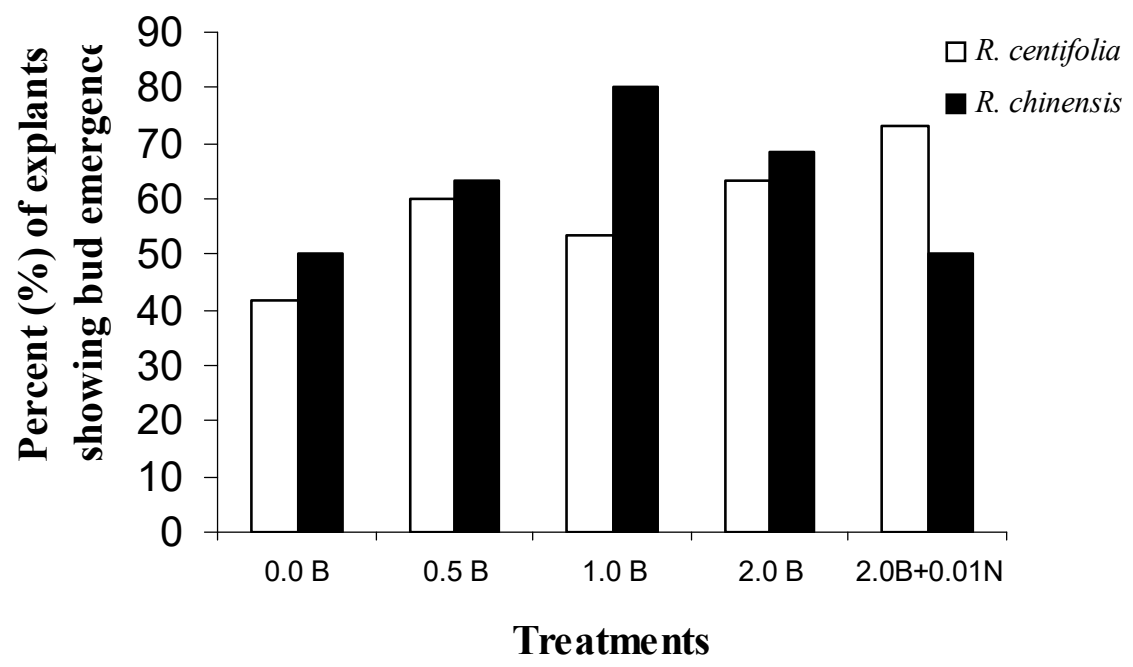

Figure 1. Percentage of nodal stem explants of Rosa centifolia cv. 'Petite de Hollande' and $R$. chinensis cv. 'Old Blush' showing emergence of axillary buds after 3 weeks of culture in agar-solidified WPM added with BAP (B) or, BAP and $\mathrm{NAA}(\mathrm{N})$ in $\mathrm{mg} \mathrm{l}^{-1}$. 
(Ara et al., 1997); and several rose species (Ma et al., 1996; Roy et al., 2004 ) except, in $R$. chinensis and $R$. centifolia. Thus, this paper reports for the first time the effects of BAP on $R$. chinensis and $R$. centrifolia cultivars.

In this study, four types of plant morphology of $R$. chinensis and $R$. centrifolia cultivars were observed depending on the culture medium and plant growth regulator supplement; (1) type 1-single shoot, (2) type 2 - multiple shoots with normal leaves, (3) type 3 - cluster of tiny shoots with curly leaves, and (4) type 4 - single shoot with callus at the base (Fig. 2). The type 1 shoot was produced through the growth of the axillary bud in plant growth regulatorfree WPM or, control medium $\left(\mathrm{S}_{0}\right)$. The type 2 shoots was obtained in medium supplemented with $1.0 \mathrm{mg} \mathrm{l}^{-1} \mathrm{BAP}\left(\mathrm{S}_{2}\right)$ and $2.0 \mathrm{mg} \mathrm{l}^{-1} \mathrm{BAP}\left(\mathrm{S}_{3}\right)$. The type 3 shoots was produced in medium containing $2.0 \mathrm{mg} \mathrm{l}^{-1} \mathrm{BAP}\left(\mathrm{S}_{3}\right)$ and, a combination of $2.0 \mathrm{mg} \mathrm{l}^{-1} \mathrm{BAP}$ and $0.01 \mathrm{mg} \mathrm{l}^{-1} \mathrm{NAA}\left(\mathrm{S}_{4}\right)$. Production of multiple adventitious shoots in BAP-containing medium agrees with the report of Kim et al. (2003). This is further supported by the findings of Huth (1978) as cited by Vieitez et al. (1983) that culture medium containing a combination of NAA and BAP was effective for shoot multiplication of apples.

An average of 1.23 to 1.87 adventitious shoots was produced from both rose species four weeks after inoculation of nodal stem segments in the agar-solidified WPM supplemented with BAP and NAA (Table 1). Four weeks after subculture (or eight weeks after explant inoculation), the average shoot production per shoot was increased to 1.33-2.17 indicating the proliferation of adventitious shoots in the BAP and NAA-supplemented media. The non-supplemented medium or, control $\left(\mathrm{S}_{0}\right)$ supported the growth of the existing shoot meristem of the axillary bud during the initial culture but did not induce shoot proliferation after subculture except, in R. chinesis cv. 'Old Bush' . All averages however, were not significantly different from each other indicating that the range of BAP and NAA concentrations incorporated in the medium had comparable effects.

The production of callus at the base of type 4 shoot was caused by high BAP concentration and/or the presence of NAA (Chawla, 2002) in the culture medium. The calli however, did not interfere with the growth and development of the shoot. The calli were non-regenerable hence, these were detached from the shoots during subculture. Callus formation of tissue cultured shoots has been observed in nodal cultures of Santalum species (Barlass et al., 1980 as cited by Vieitez et al., 1983), and from two rose species and hybrid cultivars treated with NAA and BAP combinations (Khosh-Khui and Sink, 1982). 
Table 1. Number of adventitious shoots from two rose species after 4 weeks of culture in agar-solidified WPM containing BAP (B) and NAA (N) in $\mathrm{mg} \mathrm{l}^{\mathrm{l}^{-1}}$

\begin{tabular}{llll}
\hline Rose Genotype & $\begin{array}{l}\text { Plant growth } \\
\text { regulator } \\
\text { in } \mathrm{mg} \mathrm{l}^{-1}\end{array}$ & $\begin{array}{l}\text { Ave. number of } \\
\text { shoots after } \\
\text { 4 weeks }\end{array}$ & $\begin{array}{l}\text { Ave. number of } \\
\text { shoots after 8* } \\
\text { weeks }\end{array}$ \\
\hline Rosa centifolia & $\mathrm{S}_{0}-0.0 \mathrm{~B}$ & 1.00 & 1.00 \\
cv. & $\mathrm{S}_{1}-0.5 \mathrm{~B}$ & 1.40 & 1.33 \\
'Petite de Hollande' & $\mathrm{S}_{2}-1.0 \mathrm{~B}$ & 1.87 & 2.17 \\
& $\mathrm{~S}_{3}-2.0 \mathrm{~B}$ & 1.63 & 2.13 \\
& $\mathrm{~S}_{4}-2.0 \mathrm{~B}+0.01 \mathrm{~N}$ & 1.70 & 1.87 \\
Rosa chinensis & & & 1.20 \\
cv. 'Old Blush' & $\mathrm{S}_{0}-0.0 \mathrm{~B}$ & 1.00 & 1.87 \\
& $\mathrm{~S}_{1}-0.5 \mathrm{~B}$ & 1.23 & 1.80 \\
& $\mathrm{~S}_{2}-1.0 \mathrm{~B}$ & 1.53 & 2.00 \\
& $\mathrm{~S}_{3}-2.0 \mathrm{~B}$ & 1.87 & 1.68 \\
& $\mathrm{~S}_{4}-2.0 \mathrm{~B}$ & 1.57 & \\
$+0.01 \mathrm{~N}$ & & \\
\hline *4 weeks after subculture of adventitious shoots into fresh medium &
\end{tabular}

\section{In vitro rooting of plantlets}

Axillary bud-derived plantlets ( $\sim 1.0 \mathrm{in}$. in length) bearing at least five to seven leaves produced two to three roots after two to three weeks of culture in agar-solidified WPM containing IBA (Fig. 3A, B) or IAA and, after eight weeks in plant growth regulator-free medium. The roots were white and actively growing, but gradually turned brown and stopped growing. After three weeks, the roots resumed their growth, increased in length and produced lateral roots. The plantlets also produced non-embryogenic calli at the base due to the presence of IBA and IAA in the rooting medium. These calli did not affect the rooting process and were removed during subculture of the plantlets.

The addition of IBA and IAA in the rooting medium induced the production of roots from the axillary bud-derived plantlets compared to the control or medium lacking IBA or IAA (Table 2). The average number of roots of plantlets cultured in the five treatment media was comparable. However, the addition of $0.25 \mathrm{mg} \mathrm{l}^{-1} \mathrm{IBA}$ was found to be more effective since it induced root elongation (Table 2). The result also indicated that plantlets root readily in medium containing lower IBA concentration as reported in several rose species (Norton and Boe, 1982; Chatani et al., 1996; Ma et al., 1996; Ara et al., 1997; Mohan and Ibrahim, 2000). 

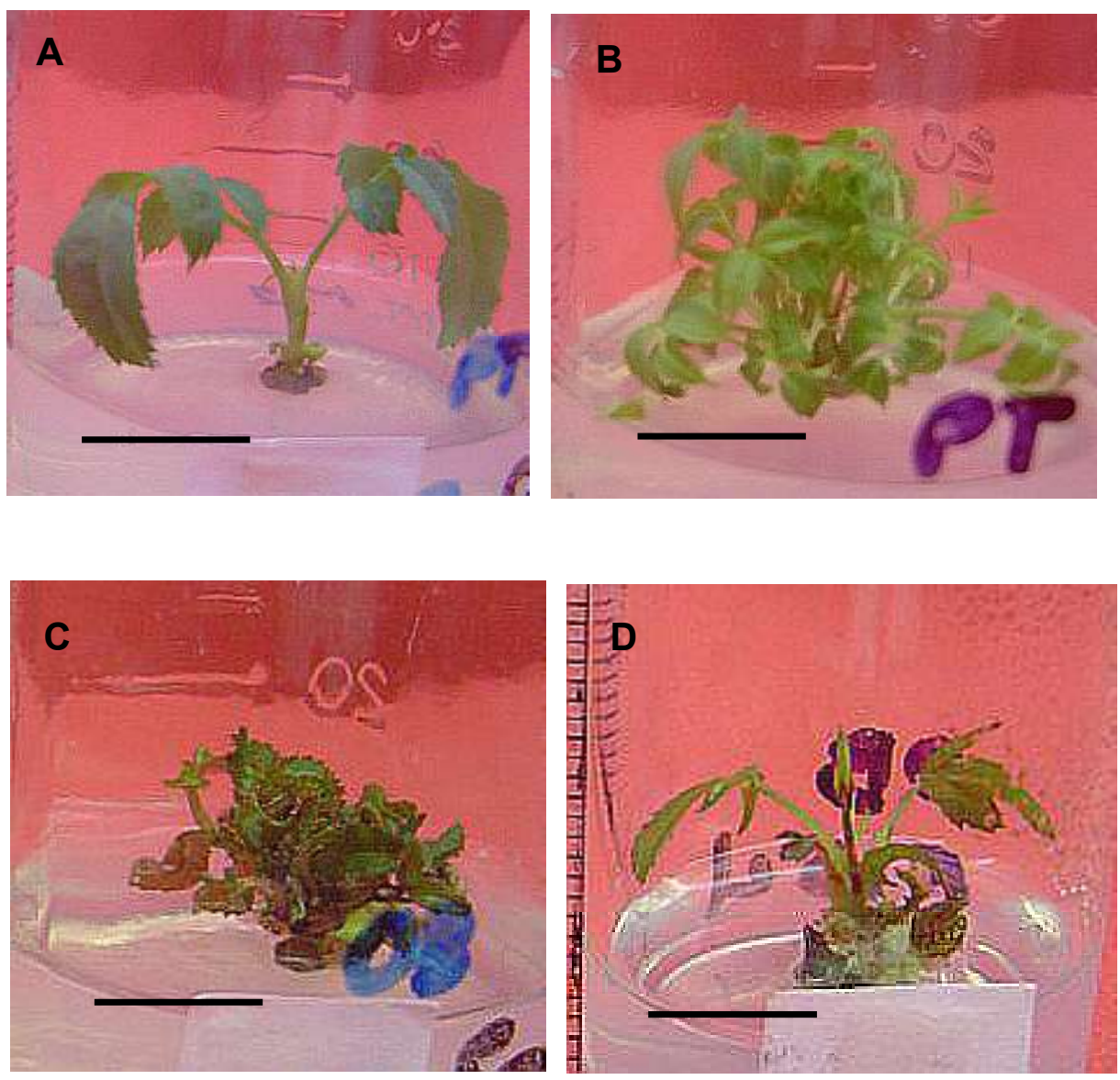

Figure 2. Four types of plant morphology from axillary bud-derived plantlets of Rosa chinensis cv. 'Old Blush.' and R. centifolia cv. 'Petite de Hollande'. (A) single shoot, (B) multiple shoots, (C) a cluster of tiny shoots with curly leaves, and (D) single shoot with callus; $(A \& B, b a r=0.7$ in.; $D \& C$, bar $=$ $0.5 \mathrm{in}$.). 
Table 2. In vitro rooting of axillary bud-derived shoots of rose species after 4 weeks of culture in agar-solidified WPM medium containing indole butyric acid (IBA) or indole acetic acid (IAA) in $\mathrm{mg} \mathrm{l}^{-1}$

\begin{tabular}{lll}
\hline Plant growth regulator $\left(\mathrm{mg}^{-1}\right)$ & $\begin{array}{l}\text { Average number } \\
\text { of roots }\end{array}$ & $\begin{array}{l}\text { Average length } \\
\text { of roots }(\mathrm{mm})\end{array}$ \\
\hline $\mathrm{R}_{0}-0.0$ & $0.00 \mathrm{~b}^{1}$ & $\mathrm{nt}^{2}$ \\
$\mathrm{R}_{1}-0.25 \mathrm{IBA}$ & $3.25 \mathrm{a}$ & $11.64 \mathrm{~b}$ \\
$\mathrm{R}_{2}-0.50 \mathrm{IBA}$ & $2.50 \mathrm{ab}$ & $8.42 \mathrm{~b}$ \\
$\mathrm{R}_{3}-1.00 \mathrm{IBA}$ & $3.55 \mathrm{a}$ & $8.36 \mathrm{~b}$ \\
$\mathrm{R}_{4}-2.00 \mathrm{IAA}^{3}$ & $1.35 \mathrm{ab}$ & $21.78^{\mathrm{a}}$ \\
\hline
\end{tabular}

${ }^{1}$ Means followed by the same letter within a column are not significantly different from each other at $5 \%$ level, Tukey HSD; ${ }^{2}$ not tested; ${ }^{3}$ based on Ma et al. (1996)

\section{Recovery and acclimatization of plantlets}

The regenerated plantlets bearing at least five roots and five to eight leaves survived the acclimatization period under ordinary room condition. However, the plantlets showed variable growth response after one to two months of transfer in Hoagland's nutrient solution (Fig. 3C) and in sterile potting medium (vermiculite, compost, and garden soil at 1:1:1; v/v) (Fig. 3D). The transplanted plantlets initially survived under ex vitro condition using the two substrates. However, after one to two months, the plantlets wilted and died. The poor establishment of plantlets in soil and in Hoagland's solution could be due to inefficient functioning of the roots produced during in vitro culture (Conger, 1981). The roots formed de novo were poorly attached to the vascular system of the shoot due to a close system formed by the xylem tissue across the shoot base prior to root formation. The plantlets also failed to form new roots in soil and nutrient solution. Thus, the conditions needed to enhance rooting and establishment of plantlets in soil need to be further investigated.

\section{CONCLUSION}

Culturing nodal stem segments in agar-solidified WPM containing BAP and NAA induced the breaking of dormancy of axillary buds of Rosa chinensis cv. 'Old Blush' and R. centifolia cv. "Petite de Hollande'. Four types of plant morphology were observed from the axillary bud-derived shoots 

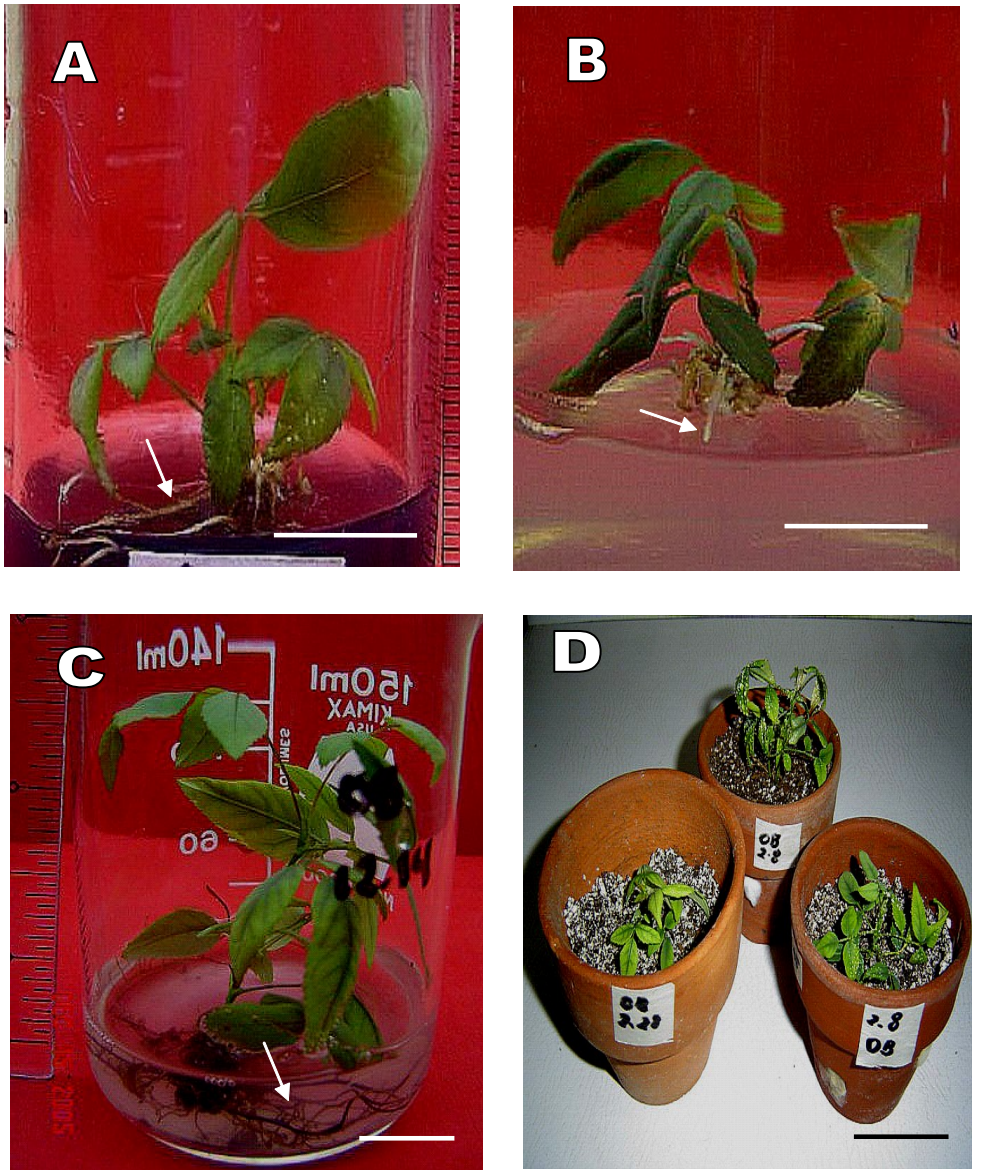

Figure 3. Rooting of Rosa centifolia cv. 'Petite de Hollande' and R. chinensis cv. 'Old Blush' plantletsin agar-solidifiedWPM containing $0.25 \mathrm{mgl}^{-1} \mathrm{IBA}(\mathrm{A}, \mathrm{B})$ and in Hoagland solution (C) prior to potting the rooted plantlets in soil (D). (AC, bar $1.0 \mathrm{~cm} ; D$, bar 1.0 in; arrows indicate adventitious roots) 
depending on the BAP and NAA supplement in the culture medium. The medium supplemented with $1.0 \mathrm{mg} \mathrm{l}^{-1} \mathrm{BAP}$ or, $2.0 \mathrm{mg} \mathrm{l}^{-1} \mathrm{BAP}$ and $0.01 \mathrm{mg} \mathrm{l}^{-}$ ${ }^{1} \mathrm{NAA}$ effectively resulted in the production of multiple shoots from both rose species. The medium containing $0.25 \mathrm{mg} \mathrm{l}^{-1} \mathrm{IBA}$ was sufficient to initiate rooting of shoots under in vitro condition. Further study is needed to increase the survival of plantlets transplanted in soil.

\section{LITERATURE CITED}

ARA, K. A., M. M. HOSSAIN, M. A. QUASEM, M. ALI, and J. U. AHMED. 1997. Micropropagation of Rose: Rosa sp. cv. 'Peace.' Plant Tissue Culture. 7(2): 135 142.

CHATANI, K., H. TOYODA, Y. MORIKAWA, and Y. OGATA. 1996. Callus induction and plant regeneration from petal explants of rose (Rosa hybrida). Plant Tissue Culture Letters 13(2):185- 188.

CHAWLA, H. S. 2002. Introduction to Plant Biotechnology, $2^{\text {nd }}$ ed. Science Publishers, Inc. Enfield (NH) USA.

CONGER, B. V. 1981. 'Agronomic Crops' In: Agricultural Crops via In Vitro Techniques (B.V. Conger, ed.). CRC Press Inc., Boca Baton, Florida, pp.166-215.

DUBOIS, L. A. M., J. ROGEMANNS, G. SOYEURT, and D. P. DE VRIES. 1988. Comparison of the growth and development of dwarf rose cultivars propagated in vitro and in vivo by softwood cuttings. Scientia Horticulturae 35.:293-299.

FLYNN, W. P., L. J. GLIECENSTEIN, and P. J. FRITZ. 1990. Theobroma cacao L. : An axillary bud in vitro propagation procedure. Plant Cell, Tissue and Organ Culture 20: 111-117.

HOAGLAND, D. R. and ARNON, D. I. 1938. The water-culture method for growing plants without soil. Univ. California Agric Exper StaCircular \#347.

HSIA, C. N. and S. S. KORBAN. 1996. Organogenesis and somatic embryogenesis in callus cultures of Rosa hybrida and Rosa chinensis Minima. Plant Cell Tissue Org. Cult. 44: 1-6.

KHOSH-KHUI, M. and K. C. SINK. 1982. Micropropagation of new and old world rose species. Journal of Horticultural Science 57(3):315-319.

KIM, C. K., J. OH, JEE, S. K. and J. D. CHUNG. 2003. In vitro micropropagation of Rosa hybrida L. J. Plant Biotechnology 5 (2):115-119. 
LLOYD, G. and B. MCGOWAN . 1980. Commercially feasible micropropagation of mountain laurel, Kalmia ratifolia, by use of shoot tip culture. Comb. Proc. Int'll. Plant Propag. Sci. 30, 321-437.

MA, Y, D. H. BYRNE and J. CHEN.1996. Propagation of rose species in vitro. IVCDBPlant 32:103-108.

MARCHANT, R., J. B. POWER, M.R.DAVEY and J.CHARTIER-HOLLIS.1994. Embryo rescue, for the production of F1 hybrids, in English rose. Euphytica 74: 187-193.

MIRO, C. 1992. Clonal Propagation of Hybrid Rose (Rosa hybrida L. cv. 'Bravo') by Tissue Culture. Undergraduate Thesis, Leyte State University, Visca, Baybay, Leyte, Philippines.

MOHAN, M. M. and S. M. IBRAHIM. 2000. Callus induction from leaf bit explants of rose. Res. on Crops 1(1):71-73.

NAKAMURA, Y. 1991. In vitro propagation of tea plants. JARQ 25(3): 185-194.

NORTON, M. E. and A. A. BOE. 1982. In Vitro Propagation of Ornamental Rosaceous Plants. HortScience 17 (2): 190.

ROY, P. K.,A. N. K.MAMUN and G. AHMED. 2004. In vitro Plantlets Regeneration of Rose. Plant Tissue Cult.14(2): 149-152.

SCHIVA, T. 2001. Floriculture Production Technology - An International Perspective. Development and International Trade - Issue and Strategies In: Strategies for Development of Commercial Floriculture in Asia and The Pacific. Asian Productivity Org., Tokyo, p.29.

SKIRVIN, R. M., M. C. CHU and H. S. YOUNG. 1990. Roses. In: Handbook of Plant Cell Culture. (P. V. Ammirato, D. E. Evans, W. R. Sharp and Y. P. S. Bajaj, eds.) U. S. A. McGraw-Hill Publishing Co., Vol. 5, pp. 716-43.

VIEITEZ, A. M. and M. L. VIEITEZ. 1980. Culture of chestnut shoots from buds in vitro. Journal of Horticultural Science 55(1): 83-84.

VIEITEZ, A. M., A. BALLESTER, M. L. VIEITEZ, and E. VIEITEZ. 1983. In vitro plantlet regeneration of mature chestnut using shoot tip explants of mature chestnut hybrids Castanea sativa x C. crenata. Journal of Horticultural Science 58(4): $457-463$.

WILKOWSKE, D. R. 1981. Propagation In Vitro of Rose. HortScience 16(3): 100. 